\title{
ANALISIS KESALAHAN DALAM MENYELESAIKAN SOAL PROGRAM LINEAR BERDASARKAN TEORI NEWMAN
}

\author{
Sumargiyani ${ }^{a}$, Indah Yusnia ${ }^{b}$, Yumna Adibah \\ ${ }^{a}$ Program Studi Pendidikan Matematika FKIP UAD \\ Jl. Ringroad Selatan, Tamanan Bantul Yogyakarta, sumargiyani04@yahoo.com \\ ${ }^{\mathrm{b}}$ Program Studi Pendidikan Matematika FKIP UAD \\ Jl. Ringroad Selatan, Tamanan Bantul Yogyakarta, indah1700006035@uad.ac.id \\ ${ }^{c}$ Program Studi Pendidikan Matematika FKIP UAD \\ Jl. Ringroad Selatan, Tamanan Bantul Yogyakarta, yumna1700006041@uad.ac.id
}

\begin{abstract}
ABSTRAK
Penelitian ini bertujuan untuk menganalisis jenis-jenis kesalahan mahasiswa dalam membentuk model matematika dan memecahkan masalah program linear dalam kehidupan sehari-hari berdasarkan teori Newman. Penelitian dilakukan dengan menggunakan pendekatan deskriptif kualitatif. Dari 28 mahasiswa kelas A semester V Prodi Pendidikan Matematika UAD Tahun Akademik 2019/2020 diambil 6 orang sebagai subyek penelitian. Tempat penelitian di kampus 4 UAD dan waktu penelitian pada semester gasal TA 2019/2020. Instrumen penelitian tes. Kesimpulan yang didapat dari hasil penelitian adalah: (1) 44,4\% mahasiswa mengalami kesalahan membaca, karena kurang cermat dalam membaca (2) 44,4\% mahasiswa salah memahami masalah, karena kurang memahami makna yang ada di dalam soal dan salah konsep (3) 33,3\% mahasiswa membuat kesalahan transformasi, karena berawal dari pemahaman konsep yang salah. (4) 33,3\% mahasiswa salah keterampilan proses, dan (5) $38,9 \%$ mahasiswa tidak dapat membuat kesimpulan dari jawaban yang diperoleh.
\end{abstract}

Kata Kunci: Analisis Kesalahan, Teori Newman, Program Linear

\section{Pendahuluan}

Mata kuliah Program Linear berbobot

3 sks sebagai mata kuliah wajib yang harus ditempuh mahasiswa program studi pendidikan matematika FKIP Universitas Ahmad Dahlan (UAD). Materi ini mempelajari tentang menyelesaikan masalah optimasi (memaksimumkan atau meminimumkan) dari fungsi tujuan dengan kendala-kendala yang terbatas.

Berdasarkan pengalaman peneliti sebagai salah satu pengampu mata kuliah

AdMathEdu | Vol.9 No.2| Desember 2019 program linear, biasanya mahasiswa masih mengalami kesulitan dalam merubah soal dalam kehidupan sehari - hari ke dalam bentuk model matematika. Padahal sebagian besar masalah yang ada di program linear merupakan masalah dalam kehidupan seharihari. Materi program linear ini, sebenarnya sudah pernah mahasiswa peroleh ketika masih duduk dibangku SLTA. Namun sebagian besar, ketika ditanya mengenai cara mengubah soal cerita dalam bentuk masalah kehidupan sehari-hari menjadi bentuk 
matematika, mahasiswa mengalami kebingungan. Sehingga diperlukan penjelasan yang detail tentang konsep cara menyelesaikan soal yang dihadapi.

Dari hasil ujian tengah semester gasal Tahun Akademik (TA) 2019/2020 untuk mata kuliah program linear di kelas A telah diperoleh hasil sebanyak 11 atau $39,3 \%$ mahasiswa yang memperoleh nilai A. Hal ini menunjukkan bahwa masih ada mahasiswa yang masih melakukan kesalahan dalam menyelesaikan soal program linear. Oleh karena ada kesalahan, menunjukkan bahwa mahasiswa masih mengalami kesultan dalam memahami dan menguasai mata kuliah progam linear. Rekapitulasi hasil nilai Ujian Tengah Semester (UTS) mata kuliah program linear yang diperoleh mahasiswa kelas A pada semester gasal TA 2019/2020 dapat dilihat pada Tabel 1.
Tabel 1. Rekapitulasi nilai UTS Program Linear Kelas A Pendidikan Matematika UAD TA 2019/2020

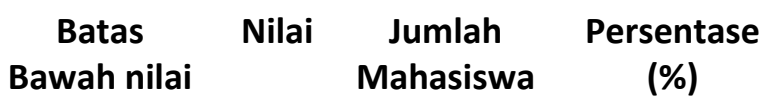

$\begin{array}{cccc}\mathbf{0} & \text { E } & 0 & 0 \\ \mathbf{4 0} & \text { D } & 2 & 7.1 \\ \mathbf{4 3 , 7 5} & \text { D+ } & 1 & 3.6 \\ \mathbf{5 1 , 2 5} & \text { C- } & 0 & 0 \\ \mathbf{5 5} & \text { C } & 2 & 7.1 \\ \mathbf{5 7 , 5} & \text { C+ } & 2 & 7.1 \\ \mathbf{6 2 , 5} & \text { B- } & 1 & 3.6 \\ \mathbf{6 5} & \text { B } & 2 & 7.1 \\ \mathbf{6 8 , 7 5} & \text { B+ } & 4 & 14.3 \\ \mathbf{7 6 , 2 5} & \text { A- } & 3 & 10.7 \\ \mathbf{8 0} & \text { A } & 11 & 39.3\end{array}$

Dari hasil di atas, menunjukkan 39,3\% mahasiswa yang memperoleh nilai maksimal. Mahasiswa yang belum mencapai nilai maksimal dikarenakan telah mengalami kesalahan-kesalahan dalam menyelesaikan soal. Kesalahan - kesalahan dalam mengerjakan soal UTS mengindikasikan mahasiswa masih mengalami kesulitan dalam menyelesaikan soal. Menurut Soedjadi dalam Mohammad Faizal Amir (2015) kesulitan yang dialami seseorang adalah penyebab terjadinya kesalahan.

Kesalahan-kesalahan yang dialami mahasiswa dalam mengerjakan soal, perlu dianalisis dan diidentifkasi guna mengatasi kesulitan yang dialami mahasiswa. Hasil dari identifikasi ini akan bermanfaat untuk pengajar dalam memperbaiki proses 
pembelajaran, pemilihan metode dan strategi dalam pembelajaran sehingga kesalahan yang dilakukan mahasiswa dalam menyelesaikan permasalahan dalam program linear dapat diminimalisir.

Salah satu alat yang dapat digunakan untuk mengenalisis kesalahan dalam memahami soal cerita adalah teori Newman. Tahapantahapan analisis kesalahan menurut teori Newman dalam Dwi Oktaviana (2017) dan Arif Fatahillah, dkk. (2017) melalui lima langkah yaitu: : (1) membaca masalah (2) memahami masalah, (3) transformasi masalah, (4) Keterampilan proses, dan (5) penarikan kesimpulan.

Berdasarkan uraian di atas, penelitian ini bertujuan untuk menganalisis jenis-jenis kesalahan mahasiswa dalam membentuk model matematika dan memecahkan masalah program linear dalam kehidupan sehari-hari berdasarkan teori Newman.pada mahasiswa kelas A program studi pendidikan matematika FKIP UAD TA 2019/2020.

\section{Metode Penelitian}

Jenis penelitian ini termasuk penelitian kualitatif deskriptif dengan menggunakan pendekatan kualitatif. Penelitian ini bertujuan untuk menganalisis jenis-jenis kesalahan mahasiswa dalam membentuk model matematika dan memecahkan masalah program linear dalam kehidupan sehari-hari berdasarkan teori Newman. Penelitian dilakukan di program studi Pendidikan Matematika FKIP UAD. Subjek dari penelitian ini yaitu 6 mahasiswa semester V kelas A yang diambil dari 28 mahasiswa yang menempuh mata kuliah program linier pada TA 2019/2020.

Prosedur pengumpulan data menggunakan tes dan wawancara. Tes dilakukan guna mengukur tingkat kemampuan pemahaman mahasiswa terkait topik bahasan. Wawancara tak terstruktur dilakukan guna memperoleh informasi yang mendalam dan lebih rinci terhadap subyek penelitian. Instrumen pada penelitian ini adalah tes dengan tiga butir soal dalam bentuk esai dan pedoman wawancara.

Analisis data yang dilakukan menggunakan tiga alur yaitu: (1) reduksi data yaitu tahap dimana peneliti merangkum dan memfokuskan data hasil analisis penelitian, mencari hal-hal penting dari data yang diperoleh atau dari jawaban mahasiswa sesuai dengan indikator yang telah ada, (2) penyajian data dalam penelitian kualitatif dilakukan dalam bentuk deskriptif atau dalam bentuk uraian singkat sesuai informasi atau data yang telah diperoleh, dan (3) Penarikan kesimpulan (Coclusin 
drawing/verification). (Imam Gunawan, 2015)

Data pada penelitian ini berupa lembar jawaban mahasiswa dalam menyelesaikan soal UTS program linear dan hasil wawancara. Dari hasil pekerjaan mahasiswa, selanjutnya dikoreksi untuk mengetahui nilai mahasiswa, kemudian hasil tes tersebut dikelompokkan ke dalam kelompok atas, kelompok tengah dan kelompok bawah. Sedangkan dari hasil wawancara digunakan untuk mendukung data yang peneliti peroleh dari lembar jawaban UTS. Teknik keabsahan temuan yang digunakan adalah teknik triangulasi sumber.

\section{Hasil dan Pembahasan}

Penelitian ini dilaksanakan pada mahasiswa semester V Kelas A Pendidikan Matematika FKIP UAD TA 2019/2020. Jumlah satu kelas terdiri dari 28 mahasiswa. Peneliti melakukan UTS semester gasal TA 2019/2020 untuk mata kuliah Program Linear dengan soal berbentuk esai sebanyak 3 soal dengan waktu pelaksanaan 60 menit. Sebelum soal diujikan, dilakukan validasi kepada penanggung jawab keilmuan. Selain itu peneliti melakukan wawancara pada 6 mahasiswa yang dipilih berdasarkan hasil UTS dengan kriteria kelompok tinggi, sedang dan rendah. Wawancara dilakukan untuk mendukung data dari hasil tes.

Adapun indikator kesalahan yang peneliti tetapkan berdasarkan teori Newman yaitu: (1) membaca masalah (reading), (2) memahami masalah (comprehension), (3) transformasi masalah (transformastion), (4) Keterampilan proses (process skil), dan (5) penarikan kesimpulan (encoding).

Hasil analisis data menunjukkan bahwa 8 mahasiswa berada pada kelompok atas, 12 mahasiswa pada kelompok tengah dan 8 mahasiswa pada kelompok bawah. Wawancara dilakukan pada subjek penelitian masing-masing 2 mahasiswa dari setiap kelompok. S1 dan S2 subyek penelitian dari kelompok atas, S3 dan S4 subyek penelitian dari kelompok tengah, dan S5 dan S6 subyek penelitian dari kelompok bawah. Persentase kesalahan yang dilakukan ke-6 subyek penelitian dalam mengerjakan 3 soal yang diberikan dalan UTS akan dijabarkan sebagai berikut. 
Tabel 2. Kesalahan pada Penyelesaian Soal

\section{Nomor 1}

$\begin{array}{cccccc}\begin{array}{c}\text { Subyek } \\ \text { penelitian }\end{array} & 1 & 2 & 3 & 4 & 5 \\ \text { S1 } & - & - & - & - & - \\ \text { S2 } & \sqrt{ } & \sqrt{ } & - & - & - \\ \text { S3 } & \sqrt{ } & \sqrt{ } & \sqrt{ } & - & - \\ \text { S4 } & - & - & - & - & - \\ \text { S5 } & \sqrt{ } & \sqrt{ } & \sqrt{ } & \sqrt{ } & - \\ \text { S6 } & \sqrt{ } & \sqrt{ } & - & - & \sqrt{ } \\ \text { Jumlah } & 4 & 4 & 2 & 1 & 1 \\ \text { Persentase } & 66.7 \% & 66.7 \% & 33.3 \% & 16.7 \% & 16.7 \%\end{array}$

Berdasarkan Tabel 2 kesalahan terbesar yang dilakukan Mahasiswa pada kesalahan membaca dan kesalahan memahami masalah. Dengan masing-masing persentase $66.7 \%$. Hal ini sejalan dengan hasil penelitian yang dilakukan oleh Mohammad Faizal Amir (2015) dimana kesalahan pemahaman konsep yang dilakukan mahasiswa lebih besar daripada kesalahan prinsip dan prosedural.

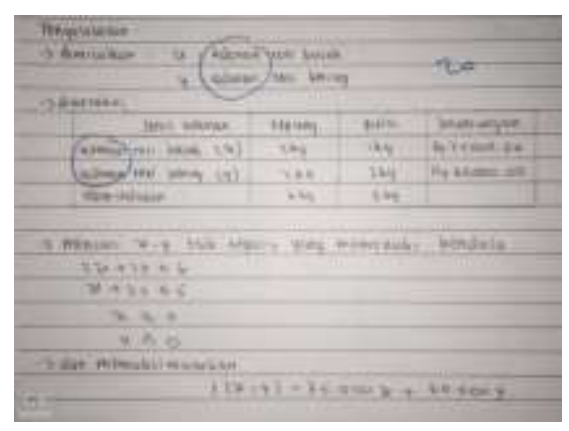

Gambar 1. Kesalahan Penyelesaian Soal

Nomor 1 dalam Membuat Model

\section{Matematika}

$\begin{array}{rlll}\text { Pada } & \text { soal nomor } & 1 & \text { mahasiswa } \\ \text { seharusnya } & \text { memisalkan } & \text { x } & \text { merupakan }\end{array}$

banyaknya roti basah dan y merupakan banyaknya roti kering. Namun, kebanyakan mahasiswa salah dalam membaca maupun memahami soal nomor 1 yang diberikan sehingga salah dalam memisalkan.

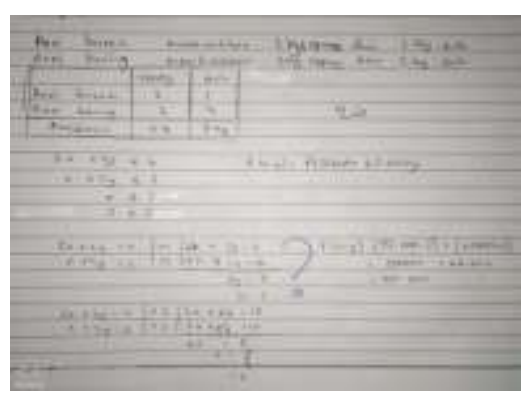

Gambar 2. Kesalahan Penyelesaian Soal Nomor 1 Memberi Jawaban yang Tidak Ditanyakan

Pada soal nomor 1 mahasiswa hanya diminta membuat model matematika saja, tetapi mahasiswa mengerjakan sampai mencari nilai fungsi tujuan pada jawaban gambar 2.

Nerdasarkan analisis data diatas, kesalahan yang dilakukan pada penyelesaian soal nomor 1 yaitu:

a. Kesalahan membaca dilakukan karena mahasiswa kurang fokus dengan apa yang menjadi tujuan dari soal sehingga salah dalam memisalkan, kurangnya latihan mengerjakan soal cerita.

b. Mahasiswa kurang teliti dalam memahami masalah dalam menentukan fungsi tujuan, kurang paham dalam memisalkan soal kedalam bentuk 
variabel, dan menuliskan jawaban yang tidak ditanyakan dalam soal.

c. Mahasiswa kesulitan dalam mentransformasikan soal cerita kedalam bentuk matematika karena panik.

Tabel 3. Kesalahan pada Penyelesaian Soal Nomor 2

$\begin{array}{cccccc}\begin{array}{c}\text { Subyek } \\ \text { penelitian }\end{array} & 1 & 2 & 3 & 4 & 5 \\ \text { S1 } & - & - & - & - & - \\ \text { S2 } & - & - & - & - & - \\ \text { S3 } & - & - & \sqrt{ } & - & - \\ \text { S4 } & - & - & - & - & - \\ \text { S5 } & \sqrt{ } & \sqrt{ } & \sqrt{ } & \sqrt{ } & \sqrt{ } \\ \text { S6 } & \sqrt{ } & \sqrt{ } & - & - & \sqrt{ } \\ \text { Jumlah } & 2 & 2 & 2 & 1 & 2 \\ \text { Persentase } & 33.3 \% & 33.3 \% & 33.3 \% & 16.7 \% & 33.3 \%\end{array}$

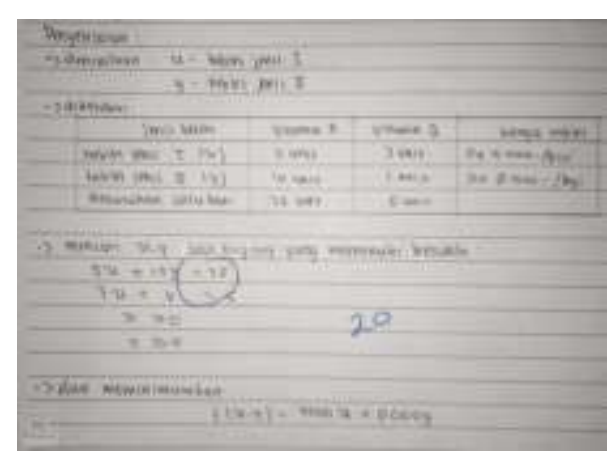

Gambar 3. Kesalahan Penyelesaian

Soal Nomor 2 Penulisan Simbol

Pertidaksamaan

Pada soal nomor 2 seharusnya kendalanya ditulis $5 x+10 y \geq 25$ dan $3 x+y \geq 5$ namun mahasiswa menuliskan kendala yang berbeda.

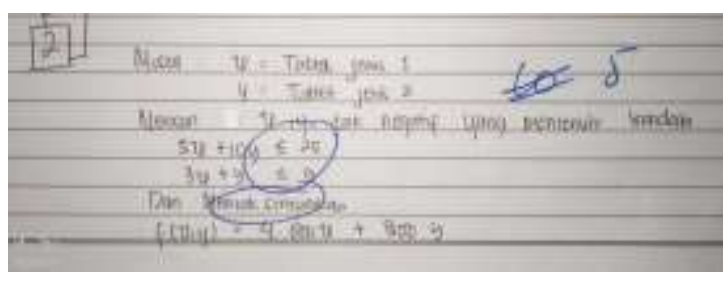

Gambar 4. Kesalahan Penyelesaian Soal Nomor 2 dalam Memahami Fungsi

Tujuan

Mahasiswa salah dalam memahami soal hal ini terlihat pada jawaban mahasiswa yang seharusnya funsi tujuannya meminimumkan tetapi ditulis memaksimumkan.

Berdasarkan Tabel 3 kesalahan terjadi disebabkan oleh:

a. Mahasiswa kurang saksama dalam membaca soal.

b. Mahasiswa kurang teliti dalam memahami tujuan soal

c. Mahasiswa masih bingung untuk merubah masalah yang ada dalam model matematika.

d. Mahasiswa menuliskan jawaban yang tidak ditanyakan dalam soal. 
Tabel 4. Kesalahan pada Penyelesaian Soal Nomor 3

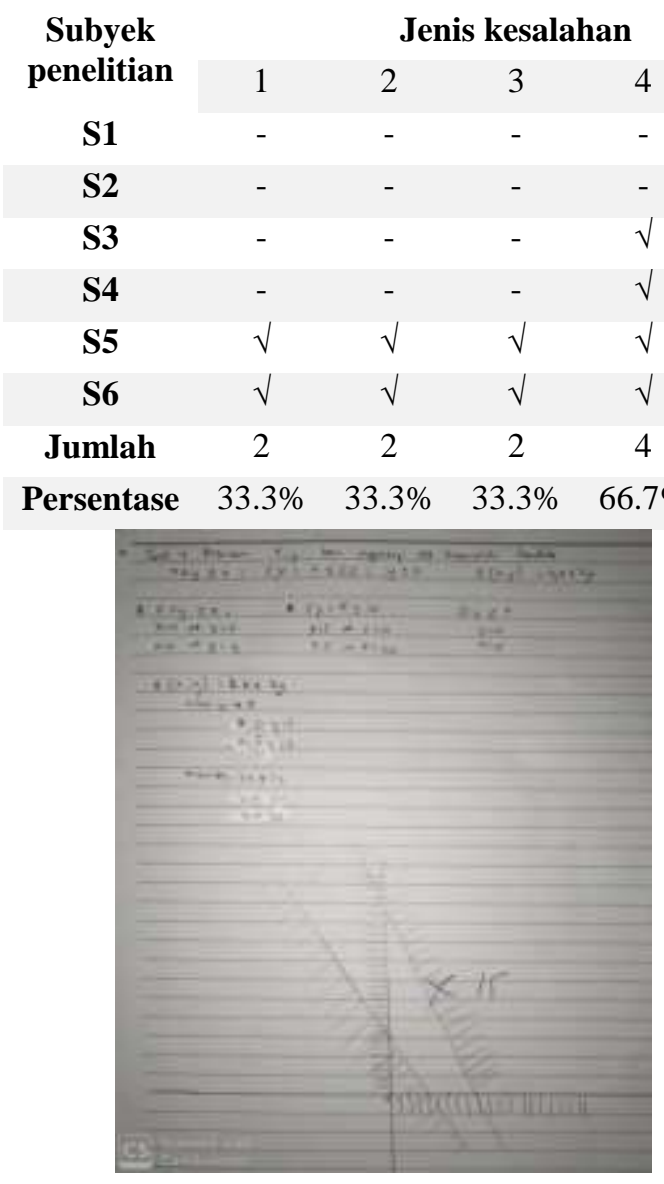

Gambar 5. Kesalahan Penyelesaian

Soal Nomor 3 dalam Mengambar Grafik

Pada soal nomor 3 mahasiswa diminta mencari penyelesaian optimum menggunakan metode grafik, dan mahasiswa salah dalam menggambarkan grafik oleh karena kesalahan terjadi pada penggambaran grafik mengakibatkan daerah layak yang dicari salah dan berakibat penyelesaian fungsi tujuannya salah. Hasil penelitian ini sesuai dengan hasil penelitian dari Indah Puspitasari, dkk., (2017) mahasiswa salah dalam menggambarkan grafik pertidaksamaan.

Berdasarkan data diatas, kesalahan yang dilakukan mahasiswa dalam mengerjakan penyelesaian soal nomor 3 yaitu:

a. Mahasiswa belum memiliki keterampilan proses dalam mengerjakan soal karena kurangnya berlatih

b. Mahasiswa belum bisa menggambar grafik dari permasalahan yang diberikan.

c. Kesalahan dalam keterampilan proses dan penarikan kesimpulan

Berdasarkan hasil analisis dari kelima jenis kesalahan yang dilakukan mahasiswa, diperoleh kesalahan terbesar terjadi pada kesalahan dalam membaca dan memahami masalah seperti terlihat pada tabel 5 berikut ini.

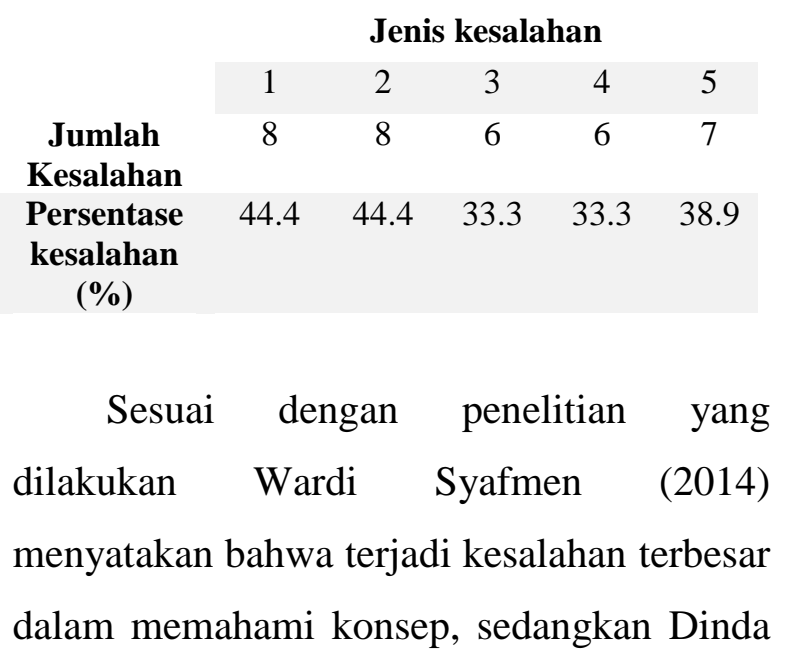

Analisis... (Sumargiyani) 
Rahmawati dan Laelatul Dhian Permata (2018) menyebutkan bahwa $81,67 \%$ terjadi kesalahan pemahaman masalah dibanding keempat kesalahan lainnya.

\section{Kesimpulan}

Dari hasil analisis kesalahan mahasiswa semester $\mathrm{V}$ pendidikan matematika FKIP UAD diperoleh simpulan sebagai berikut:

1. Kesalahan terbesar yang dilakukan mahasiswa yaitu jenis kesalahan membaca dan memahami konep.

2. Penyebab kesalahan membaca diantaranya yaitu kurang fokus, kebingungan dalam memisalkan kedalam bentuk variabel, dan kesalahan dalam menggambar grafik.

\section{Pustaka}

Amir, Mohammad Faizal. 2015. "Analisis Kesalahan Mahasiswa PGSD Universitas Muhammadiyah Sidoarjo dalam Menyelesaikan Soal Pertidaksamaan Linier". Jurnal Edukasi 1(2):131-145.

Fatahillah, Arif. Yuli Fajar Wati N.T.

Susanto. 2017. “Analisis Kesalahan Siswa dalam Menyelesaikan Soal Cerita Matematika Berdasarkan Tahapan Newman Beserta Bentuk Scaffolding yang Diberikan”. Jurnal Kadikma, 8(1) : 40-51.
Gunawan, I, 2015, “Metode Penelitian Kualitatif" tersedia di http://fip.um.ac.id/wpcontent/uploads/2015/12/3_MetpenKualitatif.pdf, Diakses tanggal 29 November 2019.

Irawati, Sri, 2015, “Analisis Kesalahan Mahasiswa Calon Guru Matematika Dalam Memecahkan Masalah Program Linier”, (http://ejournal.unira.ac.id/index.php /jurnal_sigma/article/view/110/94), Diakses tanggal 29 November 2019

Oktaviana, Dwi. 2017. Analisis Tipe Kesalahan Berdasarkan Teori Newman Dalam Menyelesaikan Soal Cerita Pada Mata Kuliah Matematika Diskrit Jurnal: edu sains vol 5(2).

Puspitasari, Indah, Ratni Purwasih, Adi Nurjaman. 2017, “Analisis Hambatan Belajar Mahasiswa Pada Mata Kuliah Program Linear". Jurnal JIPM 6(1):39-46.

Rahmawati, Dinda., Laelatul Dhian Permata. 2018, "Analisis Kesalahan Siswa Dalam Menyelesaikan Soal Cerita Program Linear Dengan Prosedur Newman" Jurnal Pembelajaran matematika 5(2): 173-185.

Rindyana, Bunga Suci Bintari \& Tjang Daniel Chandra. "Analisis Kesalahan Siswa Dalam Menyelesaikan Soal Cerita Matematika Materi Sistem Persamaan Linear Dua Variabel Berdasarkan Analisis Newman (Studi Kasus Man Malang 2 Batu)", tersedia di

(http://jurnalonline.um.ac.id/data/artike 1/artikel1B38E977F3512C05B4DF642 6CD3B167F.pdf). Diakses tanggal 29 November 2019. 
Sari, Lili Nur Indah. Rosita Dwi Ferdian.

Timbul Yuwono. 2018. "Analisis Kesalahan Dalam Menyelesaikan Soal Cerita Berdasarkan Teori Newman", Jurnal: Ibriez 1(3): 99106. 
